\title{
Opportunities for Antibody Discovery Using Human Pluripotent Stem Cells: Conservation of Oncofetal Targets
}

\author{
Heng Liang Tan ${ }^{1, *(D)}$ and Andre Choo ${ }^{1,2}$ \\ 1 Bioprocessing Technology Institute, Agency for Science, Technology and Research (A*STAR), Biopolis, \\ Singapore 138668, Singapore; andre_choo@bti.a-star.edu.sg \\ 2 Department of Biochemical Engineering, National University of Singapore, Singapore 117575, Singapore \\ * Correspondence: tan_heng_liang@bti.a-star.edu.sg
}

Received: 26 October 2019; Accepted: 13 November 2019; Published: 15 November 2019

\begin{abstract}
Pluripotent stem cells (PSCs) comprise both embryonic stem cells (ESCs) and induced pluripotent stem cells (iPSCs). The application of pluripotent stem cells is divided into four main areas, namely: (i) regenerative therapy, (ii) the study and understanding of developmental biology, (iii) drug screening and toxicology and (iv) disease modeling. In this review, we describe a new opportunity for PSCs, the discovery of new biomarkers and generating antibodies against these biomarkers. PSCs are good sources of immunogen for raising monoclonal antibodies (mAbs) because of the conservation of oncofetal antigens between PSCs and cancer cells. Hence mAbs generated using PSCs can potentially be applied in two different fields. First, these mAbs can be used in regenerative cell therapy to characterize the PSCs. In addition, the mAbs can be used to separate or eliminate contaminating or residual undifferentiated PSCs from the differentiated cell product. This step is critical as undifferentiated PSCs can form teratomas in vivo. The mAbs generated against PSCs can also be used in the field of oncology. Here, novel targets can be identified and the mAbs developed as targeted therapy to kill the cancer cells. Conversely, as new and novel oncofetal biomarkers are discovered on PSCs, cancer mAbs that are already approved by the FDA can be repurposed for regenerative medicine, thus expediting the route to the clinics.
\end{abstract}

Keywords: pluripotent stem cells; antibody discovery; regenerative cell therapy; oncology; oncofetal

\section{Introduction}

Pluripotent stem cells (PSCs) comprise both embryonic stem cells (ESCs) and induced pluripotent stem cells (iPSCs) [1,2]. The former is derived from the inner cell mass of the blastocyst while the latter is generated by reprogramming somatic cells through the introduction of pluripotent-inducing transcription factors [3-6]. Both types of PSCs exhibit similar properties of self-renewal and the ability to differentiate into cell types representing the three germ layers. Hence, PSCs are widely accepted as an inexhaustible source of cells for various applications and are prominent in the area of regenerative cell therapy. Many studies have investigated the differentiation of PSCs for the treatment of injuries and degenerative diseases such as diabetes, spinal cord injury, muscular dystrophy, cardiac and liver failure to list a few examples [7-12]. Studies have shown that PSCs can also be differentiated to innate immune cells such as natural killer cells and T-cells for cancer therapies $[13,14]$. The field of PSCs is advancing rapidly as evident from the significant increase of published research papers and the number of clinical trials with PSC derivatives, especially for the treatment of macular degeneration $[15,16]$.

To meet clinical standards and demands, the bioprocessing of PSCs is necessary and is analogous to that of manufacturing a biologics drug. A typical bioprocess for cell therapy starts from the 
"raw material" of undifferentiated PSCs, expansion, differentiation, harvesting, isolation and validation of final product prior to delivery to the clinics $[17,18]$. At every stage of the bioprocess, the cells have to be checked for quality, and one way of carrying the quality checks is through the use of monoclonal antibodies (mAbs). In addition, mAbs can also be used for isolation of the cellular products.

During the early stage of human ESC (hESC) research, the availability of biomarkers used to characterize hESCs was limited. A list of these biomarkers used for PSCs is summarized by Carpenter et al. [19]. Many of these biomarkers were originally discovered in other cell types such as embryonal carcinoma (EC) or teratocarcinoma cells, affirming the presence of oncofetal antigens on PSCs [20]. For example, the surface antigens (stage-specific embryonic antigen) SSEA-3 and SSEA-4, together with TRA-1-60 and TRA-1-81 were found to be expressed on ECs [21-25]. Hence, various groups proceeded to raise antibodies specific to surface biomarkers on hESCs with the primary objective of characterizing and validating the PSCs and to use these mAbs to "clean up" the final cell product for regenerative cell therapy. The conservation of some oncofetal antigens between embryonic cells and cancer cells also provided an opportunity to discover novel mAbs to be used in the field of targeted therapy for cancers. These mAbs can then be engineered to a variety of different formats to target and kill cancer cells, e.g., naked mAbs (antibody-dependent cell-mediated cytotoxicity, ADCC, or enhanced ADCC), antibody drug conjugate (ADC) or bispecific antibodies.

\section{2. mAbs for Regenerative Cell Therapy}

The mAbs that were originally raised against ECs or teratocarcinoma cells served well as biomarkers for PSCs. However, groups continued to generate mAbs against hESCs with the objectives of discovering novel biomarkers specific to PSCs and using these mAbs to characterize PSCs better. To achieve this, PSCs were used as immunogens. It was not surprising to note that the antigen targets of these mAbs can also be found on cancer, thus confirming the conservation of oncofetal targets between PSCs and cancers. In this section, we will give a review of some mAbs that were raised using PSCs as immunogens for the application in regenerative cell therapy.

Choi et al. raised a panel of $33 \mathrm{mAbs}$ specific to undifferentiated hESCs using a modified decoy immunization strategy, whereby mice were immunized with hESCs as the main immunogen and differentiated hESCs (in the presence of retinoic acid) [26,27]. Characterization of one of the mAbs identified the antigen target as CD9 [26]. They also identified two other mAbs that bind to surface proteins on both hESCs and cancer cell lines, though the identities of the antigens were not determined [27]. Independently, Son et al., using conventional hybridoma technology, raised a panel of mAbs against hESC, of which two mAbs were shortlisted and characterized [28,29]. The first mAb, 4-63, was found to bind to the antigen L1 cell adhesion molecule (L1CAM) on undifferentiated PSCs [28]. L1CAM was found to play an important role in self-renewal by activating fibroblast growth factor receptor 1 signaling. The second mAb binds to desmoglein-2 (DSG2) on undifferentiated hESCs, and its surface expression is rapidly downregulated upon differentiation [29]. Their studies further revealed that DSG2 is essential to the self-renewal of PSCs and the acquisition of pluripotency during somatic cell reprogramming by controlling $\beta$-catenin/slug-mediated epithelial mesenchymal transition. In another study, a panel of mAbs to cell surface antigens on hESCs was also generated [30]. Characterization of the $\mathrm{mAb}, 20-202 \mathrm{~S}$, showed that the antigen target was heat shock $70 \mathrm{kDa}$ protein 8 isoform 1 (HSPA8), which is downregulated upon differentiation. Additionally, HSPA8 protein belongs to the family of heat shock protein 70 , which is found in some cancers. Through western blotting, the mAb 20-202S was shown to bind to cancer cells (cholangiocarcinoma, sarcomatoid cholangiocarcinoma and cervical cancer) that expressed this oncofetal antigen.

Our group has also generated panels of mAbs to hESCs [31-35]. Taking a whole cell immunization approach, mAbs to podocalyxin-like protein 1 (PODXL), epithelial cell adhesion molecule (EpCAM), annexin A2 and Erbb-2 were obtained. These mAbs bind to either protein targets or glycan epitopes [36,37]. In addition to characterizing PSCs, we demonstrated the utilities of our mAbs in both regenerative cell therapy and oncology. In regenerative cell therapy, the mAbs can be used to 
purify the final cell product by removing undifferentiated PSCs through cell separation methods and cytotoxic mAbs specific to undifferentiated PSCs [31,32,36,38]. Some of the mAbs also bind to cancer cells as a result of oncofetal antigen conservation and have been developed as targeted therapies to treat cancers $[34,35]$.

Besides their use to characterize PSCs, mAbs can also be used to separate undifferentiated cells from the differentiated cell product, especially if the antigen is downregulated in the latter. One of the safety concerns associated with the use of PSCs is the presence of residual undifferentiated PSCs in the differentiated cell product. The contaminating undifferentiated PSCs can potentially form teratomas in vivo [31,32,38-40]. Hentze et al. demonstrated that 245 undifferentiated hESCs were all that was needed to form teratomas in SCID mice [41]. Fujikawa et al. showed that insulin-expressing cells derived from ES cells, post-transplanted into SCID mice, were able to form teratomas in vivo resulting in the failure of treatment for type I diabetes [42]. In another case study, researchers from Israel reported that four years after a patient was given fetal neural stem cell transplants to treat ataxia telangiectasia, the patient developed tumors in his brain and spinal cord. This case study highlights the risk of teratoma or tumor formation not just from pluripotent stem cells but also from other sources of stem cells (including fetal neural stem cells) and hence, poses a major stumbling block for cell-based therapies $[43,44]$.

In lieu of this safety concern, Kornelia et al. used mAbs that were raised against hESCs, coupled with magnetic activated cell sorting (MACS), to separate cell mixtures of undifferentiated hESCs and fibroblasts [38]. Validating the final separated product via phenotype (flow cytometry) and genomic (quantitative reverse transcription polymerase chain reaction, RT-qPCR) analysis, they were able to remove $97.2-99.7 \%$ of undifferentiated hESCs from the cell mixture. When the enriched fibroblast cells (after the one-step MACS) were transplanted into severe combined immunodeficiency (SCID) mice, 8 out of the 9 mice did not develop teratomas while the teratoma formation in the last mouse was significantly delayed. They further demonstrated that by selectively removing undifferentiated hESCs using MACS followed by treatment with a cytotoxic antibody (mAb 84) specific to undifferentiated hESCs, they were able to remove $99.1-100 \%$ of undifferentiated hESCs from the cell mixture [31,32,38].

The cytotoxic mAb specific to undifferentiated hESCs, mAb 84, that Kornelia et al. used is an IgM. The antigen target of mAb 84 was found to be podocalyxin-like protein 1 (PODXL) [31]. The calculated molecular weight of PODXL is $55 \mathrm{kDa}$ but the apparent mass in non-ES cells is approximately $160 \mathrm{kDa}$ as the protein is highly glycosylated [45]. PODXL is reported to be a biomarker of hESCs, and a study by Schopperle and DeWolf confirmed the presence of a stem cell PODXL with a molecular weight of $200 \mathrm{kDa}[46,47]$. mAb 84 kills PSCs rapidly via oncosis, by forming pores on the plasma membrane, probably because of antigen aggregation by the IgM [32]. When hESCs were pre-treated with $\mathrm{mAb} 84$ and injected into SCID mice, they were able to prevent the formation of teratomas even up to 20 weeks and consequently, enhance the safety of PSC regenerative therapy.

Matsumoto et al. reported another cytotoxic mAb which was generated using iPSCs as the immunogen [48]. The mAb, R-17F, is an IgG1 and was found to specifically bind to PSCs but not to ECs. R-17F kills PSCs in a dose-dependent manner and its cytotoxicity was significantly enhanced through hyper-crosslinking with a secondary antibody. Unlike mAb 84, R-17F does not bind to a glycoprotein and its epitope was identified as the glycolipid lacto- $N$-fucopentose I (LNFP I).

Two other mAbs, A1 and mAb-A4, have been reported to kill undifferentiated PSCs and bind to glycan epitopes [36,37]. $\mathrm{mAb} A 1$, is an IgG and the mechanism with which A1 kills PSCs was also elucidated to be oncosis. Unlike the $\operatorname{IgM} \mathrm{mAb} 84$, oncosis by A1 is mediated by excess reactive oxygen species production [36]. Another antibody, mAb-A4, an IgM, was also found to kill PSCs rapidly [37]. Interestingly, both mAbs recognized glycan epitopes expressed on multiple proteins. Via glycan inhibition assays, A1 was found to bind to glycans containing the motif Fuc $\alpha 1-2 \mathrm{Gal} \beta 1-3 \mathrm{GlcNAc} \beta 1-3 \mathrm{Gal} \beta 1$. Using a combination of techniques and assays (enzymatic digestion with glycosidases, glycan microarrays, siRNA and high sensitivity matrix-assisted laser desorption/ionization mass spectrometry), the terminal epitopes of mAb-A4 were found to be 
type 1 LacNAc and $\mathrm{H}$ type 1 sugars. Tang et al. also reported of a mAb, SSEA-5, which binds to the glycan $\mathrm{H}$ type 1 that is highly and specifically expressed in PSCs [49]. In their study, they showed that a combination of SSEA- 5 with two other pluripotent surface markers is sufficient to remove teratoma formation potential of PSCs.

Recently, our group proposed a strategy to complement existing methods that eliminate teratoma-forming cells in vitro [50]. Residual undifferentiated PSCs could possibly escape in vitro removal methods and be introduced into patients together with the differentiated cells. Here, we demonstrated that $\mathrm{mAbs}$, which elicit antibody-dependent cell-mediated cytotoxicity (ADCC) or as an antibody drug conjugate (ADC), can be included as an additional safeguard to eliminate these "escaped" undifferentiated cells that are circulating in the body and consequently enhance the safety of PSCs-derived cell therapies. As a proof of concept, mAb 2448, which targets annexin A2 on PSCs, was able to eliminate hESCs in vivo via both ADCC and ADC mechanisms of action. Interestingly, the ADC when administered at a site away from the cell transplant was still able to home towards the circulating undifferentiated PSCs and prevent or delay teratoma formation.

Hence, in the process of raising antibodies to surface proteins of PSCs, novel biomarkers were discovered and can be used to characterize the undifferentiated PSCs. Table 1 provides a summary of the mAbs highlighted in this review section. These biomarkers can be either protein or glycan in nature. In addition to using them to characterize PSCs, these mAbs can also be used in combination to separate and "clean up" the undifferentiated PSCs from final cell products, prevent teratoma formation in vivo and consequently make PSC-derived regenerative cell therapies safer.

Table 1. Summary of mAbs generated against PSCs and used for regenerative cell therapy.

\begin{tabular}{|c|c|c|c|c|c|}
\hline mAbs & Immunogen & Antigen Target & Antigen Type ${ }^{1}$ & $\begin{array}{l}\text { Cells that } \\
\text { mAbs Bind }{ }^{1}\end{array}$ & Authors (References) \\
\hline L125-C2 & hESC & CD9 & Protein & PSC & Choi et al. [26] \\
\hline 63-B6 & hESC & $\mathrm{ND}^{2}$ & Protein & $\begin{array}{l}\text { PSC, EC, } \\
\text { Cancers }\end{array}$ & Kim et al. [27] \\
\hline 246-D7 & hESC & $\mathrm{ND}^{2}$ & Protein & $\begin{array}{l}\text { PSC, EC, } \\
\text { Cancers }\end{array}$ & Kim et al. [27] \\
\hline $4-63$ & hESC & L1CAM & Protein & PSC & Son et al. [28] \\
\hline K6-1 & hESC & DSG2 & Protein & PSC & Park et al. [29] \\
\hline $20-202 S$ & hESC & HSPA8 & Protein & PSC, Cancers & Son et al. [30] \\
\hline $\mathrm{mAb} 84$ & hESC & PODXL & Glycoprotein & PSC, EC & $\begin{array}{c}\text { Choo. et al. } \\
\text { Tan et al. } \\
{[31,32]}\end{array}$ \\
\hline R-17F & iPSC & Lacto- $N$-fucopentose I & Glycolipid & PSC & Matsumoto. et al. [48] \\
\hline A1 & hESC & Fuc $\alpha 1-2$ Gal $\beta 1-3$ GlcNAc $\beta 1-3 G a l \beta 1$ & Glycan & PSC & Zheng et al. (36) \\
\hline mAb-A4 & hESC & $\begin{array}{l}\text { Type } 1 \text { LacNAc } \\
\text { and H Type } 1\end{array}$ & Glycan & PSC, Cancers & Choo. et al. [37] \\
\hline SSEA-5 & hESC & H Type 1 & Glycan & PSC & Tang. et al. [49] \\
\hline 2448 & hESC & Annexin A2 & Glycoprotein & PSC, Cancers & Tan et al. [50] \\
\hline
\end{tabular}

${ }^{1}$ As reported by authors; ${ }^{2}$ ND: Not determined; EC, embryonal carcinoma; PSCs include either human embryonic stem cells (hESCs)/induced pluripotent stem cells (iPSCs) or both in this table.

\section{3. mAbs for Oncology}

From the list of mAbs in Table 1, it is evident that many of the antigen targets identified on PSCs are also expressed on cancer cells [51-57]. This is not surprising as there are many studies that support the conservation of antigens between embryonic cells and cancer cells [58-62]. Historically, fetal and embryonic materials have also been investigated and used as alternatives for cancer treatment. Schöne found that immunization of mice with fetal material resulted in the rejection of transplanted tumors. Fibiger and Moeller extended this study and showed that immunization of fetal skin into mice prevented the growth and metastasis of coal tar-induced carcinoma [58]. In recent studies, immunization of mice with either human fetal tissues or PSCs showed strong protection 
against cancer tumor establishment and proliferation [59,60]. Antigens associated with embryonic and fetal development, which are also found in cancers, are classified as oncofetal antigens. For example, the surface markers TRA-1-60 and the SSEA-3, originally raised against ECs, were also identified in breast and prostate cancer subpopulations [61]. Some other common oncofetal antigens that are used as biomarkers in oncology include cancer antigen 125 (CA125 or Mucin16) for ovarian cancer, the sialylated Lewis A antigen CA19-9 for pancreatic cancer, $\alpha$-fetoprotein (AFP) for hepatocellular cancer and germ cell tumors and prostate-specific antigen (PSA) [62-64]. As described earlier, mAb 84 binds to PODXL on hESCs [31,32]. PODXL is reported to be expressed in multiple cancer types such as breast, esophageal, colorectal cancers, lung and gastric adenocarcinoma, pancreatic and urothelial bladder cancers [65-73]. Besides their applications in PSC-derived regenerative cell therapies, mAbs against PSCs also provide the opportunity to discover novel $\mathrm{mAbs}$ and new biomarkers against cancers. For example, Kim et al., Son et al. and Choo et al. (Table 1) reported that their mAbs raised against hESCs also bind to cancer cells $[27,30,37]$.

When mAbs bind to the targeted cancer cells, they are able to kill the cells through various mechanisms of action (MOAs). The Fc-region of antibodies plays an important role in the activation of immune cells and the killing of targeted cells via ADCC and also in mediating cell killing through complement-mediated cytotoxicity (CDC) [74-78]. Antibodies can also cause vascular and stromal cell ablation, affecting cancer cell proliferation. Alternatively, antibodies can neutralize or block the binding of growth factors to the respective receptors and consequently inhibit cell proliferation [74-77]. They can also mediate direct cell killing by the activation of apoptotic pathways or via oncosis [75,76,78-81]. Antibodies can also internalize into the targeted cells and deliver payloads, such as drugs, cytotoxic or radiation agents, to directly kill the cancer cells [74-76,78]. Hence, oncofetal antigens are promising targets for antibody-based therapies against cancers. In this section, we will highlight some mAbs that were generated against hESCs. These hESC mAbs also bound to various cancers, and some were able to kill the cancer cells via various MOAs and cause tumor regression in vivo.

$\mathrm{Ng}$ et al. reported a mAb raised against hESCs [33]. Through immuno-precipitation and mass spectrometry, the antigen target of this $\mathrm{mAb}(\mathrm{mAb} 8)$ was found to be epithelial cell adhesion molecule (EpCAM). This biomarker is shown to be a surface marker on undifferentiated hESCs and the expression of EpCAM is downregulated upon differentiation. Knockdown and silencing of EpCAM via small interfering ribonucleic acid (siRNA) and short hair RNA (shRNA) had a marginal effect on the expression of other pluripotent markers (OCT-4, TRA-1-60 and NANOG) in hESCs but decreased the proliferation of hESCs significantly. Interestingly, teratoma formation was comparable between the EpCAM shRNA cells and control. However, through gene expression analysis of the teratomas, the EpCAM shRNA samples demonstrated the greatest significant increase in the endoderm marker AFP. EpCAM is reported to be highly expressed in epithelial carcinomas and also expressed in numerous cancers such as ovarian, breast, colorectal adenocarcinomas and gastric cancers [82-88]. This is consistent with our observation that $\mathrm{mAb} 8$ also binds to various cancer cell lines, including breast and ovarian cancers.

Another hESC mAb, 2448, binds to annexin A2 on hESCs and on cancer cells [34,50]. Cua et al. showed that the $\mathrm{mAb}$ binds to glycans on annexin $\mathrm{A} 2$, which confers the $\mathrm{mAb}$ a unique property. The $\mathrm{mAb}$ binds specifically to cancer cells with epithelial phenotype. Upon binding to ovarian and breast cancer cells, 2448 is able to internalize into the cells and when developed as an ADC, the mAb was able to kill the cancer cells in vitro. The $\mathrm{mAb}$ was also chimerized from a mouse IgG with a human IgG1 backbone. The chimerized 2448 was able to elicit ADCC in vitro, and further engineering of the chimeric $\mathrm{mAb}$ to remove fucose in the Fc domain enhanced the ADCC more than 20-fold. in vivo, the chimerized $\mathrm{mAb}$ was able to home in to the tumors and cause tumor regression in ovarian xenograft models [34].

In a study by Tan et al., the mAb, A19, bound to breast and ovarian cancer cells [35]. The antigen target of A19 was identified as Erbb-2. Errb-2 is highly expressed on hESCs and many cancers and plays an important role in cell proliferation $[89,90]$. This antigen serves as a good target for Herceptin, 
which is the gold standard for targeted therapy in the clinics to treat HER2 positive breast cancers and gastric cancers [91-93]. Tan et al. also demonstrated that the epitope of the A19 is N-glycan on the protein and binds to isoforms different to Herceptin [35]. Unlike 2448, the chimeric A19 does not elicit ADCC but, when developed as an ADC, was able to kill the cancer cells in vitro. In xenograft models, under sub-optimal conditions, the ADC was able to reduce the volume of the tumors by $60 \%$ compared to the controls.

The conservation of oncofetal targets (proteins or glycans) enabled mAbs that were originally generated against PSCs to be repurposed for targeted therapy in cancers (Table 2). mAbs have been a success as targeted therapies in the clinics and are able to elicit various MOAs to kill cancer cells. However, a major challenge is finding new biomarkers to target the cancer cells. Furthermore, many oncology mAbs are raised towards a specific disease indication. Hence, anti-PSC mAbs provide the opportunities for discovery of new biomarkers in a non-biased manner, and these mAbs can be repurposed for oncology.

Table 2. Summary of mAbs generated against PSCs and used in oncology.

\begin{tabular}{ccccccc}
\hline mAbs & Immunogen & $\begin{array}{c}\text { Antigen } \\
\text { Target }\end{array}$ & Antigen Type $\mathbf{1}^{\text {A }}$ & $\begin{array}{c}\text { Cells that } \\
\text { mAbs Bind }{ }^{\mathbf{1}}\end{array}$ & $\begin{array}{c}\text { Mechanism of } \\
\text { Action (MOA) }\end{array}$ & $\begin{array}{c}\text { Authors } \\
\text { (References) }\end{array}$ \\
\hline mAb 8 & hESC & EpCAM & Protein & PSC, Cancers & No MOA & Ng et al. [33] \\
\hline AESC & Annexin A2 & Glycoprotein & PSC, Cancers & $\begin{array}{c}\text { Internalization } \\
\text { (ADC), ADCC }\end{array}$ & Cua et al. [34] \\
\hline hESC & Erbb-2 & Glycoprotein & PSC, Cancers & $\begin{array}{c}\text { Internalization } \\
\text { (ADC) }\end{array}$ & Tan et al. [35] \\
\hline
\end{tabular}

${ }^{1}$ As reported by authors; PSCs include either hESCs/iPSCs or both in this table; ADC, antibody drug conjugate; ADCC, antibody-dependent cell-mediated cytotoxicity; EPCAM, epithelial cell adhesion molecule.

\section{Discussion}

In this review, we summarized some mAbs that were generated following mice immunization with PSCs. Subsequently, these mAbs were also found to bind cancer cells due to the conservation of oncofetal targets between embryonic and cancer cells. These studies also provided the opportunities for the identification of novel conserved antigens, and interestingly, the majority of the antigen targets, which are expressed on both PSCs and cancer cells, are glycoproteins.

It is to be noted that the expression of oncofetal antigens is not limited to PSCs. Studies have also shown that these antigens can also be expressed on fetal cells, which may also be used as immunogens to raise mAbs against cancers [94]. At the same time, some of these oncofetal antigens are biomarkers in both cancers and differentiated PSCs. For example, $\alpha$-fetoprotein (AFP) and carcinoembryonic antigen (CEA) are expressed in cancers but also upregulated in PSC-derived hepatocytes and dendritic cells, respectively [95-102]. However, a distinguishing feature of cancer cells/PSCs from normal/differentiated cells could be the post-translational modifications (e.g., glycans) of these antigens, which serve as an additional layer of resolution between the cell types and cell stages [103,104]. An example of this was reported previously by Schopperle and DeWolf [47]. They identified the presence of a stem-cell-specific PODXL on PSCs, which was different from non-ES cells due to differences in the glycan profile [47].

In this review, we focus on mAbs raised against PSCs. This duality in binding enables the mAbs to be used for both stem cell and cancer cell applications. In regenerative cell therapy, the mAbs can be used to characterize the PSCs. The mAbs can also be used for cell separation and to remove contaminating or residual undifferentiated PSCs from the final differentiated cell product. This step is critical in making PSC regenerative therapy safer as undifferentiated PSCs can form teratomas in vivo. Due to the conservation of oncofetal targets between embryonic and cancer cells, many of the mAbs against PSCs bind to cancer cells. For oncology applications, these mAbs can then be engineered to a variety of different formats to target and kill cancer cells, e.g., naked mAbs (ADCC or enhanced ADCC), ADC or bispecific antibodies. 
The biomarkers identified in Tables 1 and 2 reinforce the concept of oncofetal antigen conservation between embryonic stem cells and cancer cells. As mentioned, oncology mAbs are usually raised towards specific disease indications. PSCs can be used as unbiased sources to generate mAbs for oncology applications and treating various types of cancers. Conversely, there are reports of mAbs that are used as targeted therapy to treat cancers and have been found to bind to undifferentiated PSCs. Sougawa et al. demonstrated that the FDA-approved ADC, brentuximab vedontin, is able to eliminate undifferentiated CD30-positive human induced pluripotent stem cells (hiPSCs) during cardiomyocyte differentiation and prevent teratoma formation [105].

In conclusion, mAbs against PSCs have dual use in the fields of regenerative medicine and targeted therapy for oncology. The many FDA-approved mAbs, which were developed for cancer therapies, can also be explored and used to characterize PSCs, thereby making regenerative therapies safer and expediting the development route of these mAbs to the clinics.

Author Contributions: H.L.T. conceived, designed and wrote the manuscript. A.C. conceived, designed and approved the manuscript.

Acknowledgments: The authors would like to thank the Agency for Science Technology and Research (A*STAR) for the generous funding of this project. We would also like to thank the ever-loving Jayanthi Padmanabhan for proofreading this manuscript.

Conflicts of Interest: The authors declare no conflict of interest.

\section{References}

1. Dakhore, S.; Nayer, B.; Hasegawa, K. Human pluripotent stem cell culture: Current status, challenges, and advancement. Stem Cells Int. 2018, 2018, 7396905. [CrossRef] [PubMed]

2. Seong Gyu, K.; Yang Woo, K.; Tae Wook, L.; Gyu Tae, P.; Jae Ho, K. Recent advances in stem cell therapeutics and tissue engineering strategies. Biomater. Res. 2018, 22, 1-8.

3. Reubinoff, B.E.; Pera, M.F.; Fong, C.-Y.; Trounson, A.; Bongso, A. Embryonic stem cell lines from human blastocysts: Somatic differentiation in vitro. Nat. Biotechnol. 2000, 18, 399-404. [CrossRef] [PubMed]

4. Thomson, J.A.; Itskovitz-Eldor, J.; Shapiro, S.S.; Waknitz, M.A.; Swiergiel, J.J.; Marshall, V.S.; Jones, J.M. Embryonic stem cell lines derived from human blastocysts. Science 1998, 282, 1145-1147. [CrossRef] [PubMed]

5. Yamanaka, S. Induction of pluripotent stem cells from mouse fibroblasts by four transcription factors. Cell Prolif. 2007, 41, 51-56. [CrossRef]

6. Takahashi, K.; Tanabe, K.; Ohnuki, M.; Narita, M.; Ichisaka, T.; Tomoda, K.; Yamanaka, S. Induction of pluripotent stem cells from adult human fibroblasts by defined factors. Cell 2007, 131, 861-872. [CrossRef]

7. Skyler, J.S. Hope vs hype: Where are we in type 1 diabetes? Diabetologia 2018, 61, 509-516. [CrossRef]

8. Nagoshi, N.; Okano, H. iPSC-derived neural precursor cells: Potential for cell transplantation therapy in spinal cord injury. Cell Mol. Life Sci. 2018, 75, 989-1000. [CrossRef]

9. Ortiz-Vitali, J.; Darabi, R. iPSCs as a platform for disease modeling, drug screening, and personalized therapy in muscular dystrophies. Cells 2019, 8, 20. [CrossRef] [PubMed]

10. Magli, A.; Perlingeiro, R.R.C. Myogenic progenitor specification from pluripotent stem cells. Semin. Cell Dev. Biol. 2017, 72, 87-98. [CrossRef]

11. Narazaki, G.; Uosaki, H.; Teranishi, M.; Okita, K.; Kim, B.; Matsuoka, S.; Yamanaka, S.; Yamashita, J.K. Directed and systematic differentiation of cardiovascular cells from mouse induced pluripotent stem cells. Circulation 2008, 118, 498-506. [CrossRef] [PubMed]

12. Horisawa, K.; Suzuki, A. Cell-Based regenerative therapy for liver disease. In Innovative Medicine; Springer: Tokyo, Japan, 2015; pp. 327-339. ISBN 9784431556503.

13. Bernarreggi, D.; Pouyanfard, S.; Kaufman, D.S. Development of innate immune cells from human pluripotent stem cells. Exp. Hematol. 2019, 71, 13-23. [CrossRef]

14. Montel-Hagen, A.; Crooks, G.M. From pluripotent stem cells to T cells. Exp. Hematol. 2019, 71, $24-31$. [CrossRef] [PubMed] 
15. Guhr, A.; Kobold, S.; Seltmann, S.; Seiler Wulczyn, A.E.M.; Kurtz, A.; Löser, P. Recent trends in research with human pluripotent stem cells: Impact of research and use of cell lines in experimental research and clinical trials. Stem Cell Rep. 2018, 11, 485-496. [CrossRef] [PubMed]

16. Angelos, M.G.; Kaufman, D.S. Pluripotent stem cell applications for regenerative medicine. Curr. Opin. Organ Transpl. 2015, 25, 1. [CrossRef] [PubMed]

17. Ratcliffe, E.; Thomas, R.J.; Williams, D.J. Current understanding and challenges in bioprocessing of stem cell-based therapies for regenerative medicine. Br. Med. Bull. 2011, 100, 137-155. [CrossRef]

18. Abbasalizadeh, S.; Baharvand, H. Technological progress and challenges towards cGMP manufacturing of human pluripotent stem cells based therapeutic products for allogeneic and autologous cell therapies. Biotechnol. Adv. 2013, 31, 1600-1623. [CrossRef] [PubMed]

19. Carpenter, M.K.; Frey-Vasconcells, J.; Rao, M.S. Developing safe therapies from human pluripotent stem cells. Nat. Biotechnol. 2009, 27, 606-613. [CrossRef] [PubMed]

20. Choi, H.S.; Kim, W.T.; Ryu, C.J. Antibody approaches to prepare clinically transplantable cells from human embryonic stem cells: Identification of human embryonic stem cell surface markers by monoclonal antibodies. Biotechnol. J. 2014, 9, 915-920. [CrossRef] [PubMed]

21. Fox, N.W.; Damjanov, I.; Knowles, B.B.; Solter, D. Stage-specific embryonic antigen 3 as a marker of visceral extraembryonic endoderm. Dev. Biol. 1984, 103, 263-266. [CrossRef]

22. Kannagi, R.; Cochran, N.A.; Ishigami, F.; Hakomori, S.; Andrews, P.W.; Knowles, B.B.; Solter, D. Stage-Specific embryonic antigens (SSEA-3 and -4) are epitopes of a unique globo-series ganglioside isolated from human teratocarcinoma cells. EMBO J. 1983, 2, 2355-2361. [CrossRef] [PubMed]

23. Kannagi, R.; Levery, S.B.; Ishigami, F.; Hakomori, S.; Shevinsky, L.H.; Knowles, B.B.; Solter, D. New globoseries glycosphingolipids in human teratocarcinoma reactive with the monoclonal antibody directed to a developmentally regulated antigen, stage-specific embryonic antigen 3. J. Biol. Chem. 1983, 258, 8934-8942. [PubMed]

24. Andrews, P.W.; Fenderson, B.; Hakomori, S. Human embryonal carcinoma cells and their differentiation in culture. Int. J. Androl. 1987, 10, 95-104. [CrossRef] [PubMed]

25. Badcock, G.; Pigott, C.; Goepel, J.; Andrews, P.W. The human embryonal carcinoma marker antigen TRA-1-60 is a sialylated keratan sulfate proteoglycan. Cancer Res. 1999, 59, 4715-4719. [PubMed]

26. Choi, H.S.; Kim, H.; Won, A.; Kim, J.J.; Son, C.Y.; Kim, K.S.; Ko, J.H.; Lee, M.Y.; Kim, C.H.; Ryu, C.J. Development of a decoy immunization strategy to identify cell-surface molecules expressed on undifferentiated human embryonic stem cells. Cell Tissue Res. 2008, 333, 197-206. [CrossRef] [PubMed]

27. Kim, J.-J.; Choi, H.S.; Lee, M.-Y.; Ryu, C.J. Characterization of Monoclonal Antibodies Recognizing 130 kDa Surface Proteins on Human Embryonic Stem Cells and Cancer Cell Lines. Monoclon. Antib. Immunodiagn. Immunother. 2013, 32, 136-139. [CrossRef] [PubMed]

28. Son, Y.S.; Seong, R.H.; Ryu, C.J.; Cho, Y.S.; Bae, K.-H.; Chung, S.J.; Lee, B.; Min, J.-K.; Hong, H.J. Brief report: L1 cell adhesion molecule, a novel surface molecule of human embryonic stem cells, is essential for self-renewal and pluripotency. Stem Cells 2011, 29, 2094-2099. [CrossRef]

29. Park, J.; Son, Y.; Lee, N.G.; Lee, K.; Lee, D.G.; Song, J.; Lee, J.; Kim, S.; Cho, M.J.; Jang, J.-H.; et al. DSG2 is a functional cell surface marker for identification and isolation of human pluripotent stem cells. Stem Cell Rep. 2018, 11, 115-127. [CrossRef]

30. Son, Y.S.; Park, J.H.; Kang, Y.K.; Park, J.-S.; Choi, H.S.; Lim, J.Y.; Lee, J.E.; Lee, J.B.; Ko, M.S.; Kim, Y.; et al. Heat shock 70-kDa protein 8 isoform 1 is expressed on the surface of human embryonic stem cells and downregulated upon differentiation. Stem Cells 2005, 23, 1502-1513. [CrossRef] [PubMed]

31. Choo, A.B.; Tan, H.L.; Ang, S.N.; Fong, W.J.; Chin, A.; Lo, J.; Zheng, L.; Hentze, H.; Philp, R.J.; Oh, S.K.W.; et al. Selection against undifferentiated human embryonic stem cells by a cytotoxic antibody recognizing podocalyxin-like protein-1. Stem Cells 2008, 26, 1454-1463. [CrossRef] [PubMed]

32. Tan, H.L.; Fong, W.J.; Lee, E.H.; Yap, M.; Choo, A. mAb 84, a cytotoxic antibody that kills undifferentiated human embryonic stem cells via oncosis. Stem Cells 2009, 27, 1792-1801. [CrossRef] [PubMed]

33. Ng, V.Y.; Ang, S.N.; Chan, J.X.; Choo, A.B.H. Characterization of epithelial cell adhesion molecule as a surface marker on undifferentiated human embryonic stem cells. Stem Cells 2010, 28, 29-35. [CrossRef]

34. Cua, S.; Tan, H.L.; Fong, W.J.; Chin, A.; Lau, A.; Ding, V.; Song, Z.; Yang, Y.; Choo, A. Targeting of embryonic annexin A2 expressed on ovarian and breast cancer by the novel monoclonal antibody 2448 . Oncotarget 2018, 9, 13206-13221. [CrossRef] [PubMed] 
35. Tan, H.L.; Yong, C.; Tan, B.Z.; Fong, W.J.; Padmanabhan, J.; Chin, A.; Ding, V.; Lau, A.; Zheng, L.; Bi, X.; et al. Conservation of oncofetal antigens on human embryonic stem cells enables discovery of monoclonal antibodies against cancer. Sci. Rep. 2018, 8, 11608. [CrossRef] [PubMed]

36. Zheng, J.Y.; Tan, H.L.; Matsudaira, P.T.; Choo, A. Excess reactive oxygen species production mediates monoclonal antibody-induced human embryonic stem cell death via oncosis. Cell Death Differ 2017, 24, 546-558. [CrossRef]

37. Choo, M.; Tan, H.L.; Ding, V.; Castangia, R.; Belgacem, O.; Liau, B.; Hartley-Tassell, L.; Haslam, S.M.; Dell, A.; Choo, A. Characterization of $\mathrm{H}$ type 1 and type $1 \mathrm{~N}$-acetyllactosamine glycan epitopes on ovarian cancer specifically recognized by the anti-glycan monoclonal antibody mAb-A4. J. Biol. Chem. 2017, 292, 6163-6176. [CrossRef] [PubMed]

38. Schriebl, K.; Satianegara, G.; Hwang, A.; Tan, H.L.; Fong, W.J.; Yang, H.H.; Jungbauer, A.; Choo, A. Selective Removal of Undifferentiated Human Embryonic Stem Cells Using Magnetic Activated Cell Sorting Followed by a Cytotoxic Antibody. Tissue Eng Part A 2012, 18, 899-909. [CrossRef] [PubMed]

39. Ben-David, U.; Benvenisty, N. The tumorigenicity of human embryonic and induced pluripotent stem cells. Nat. Rev Cancer 2011, 11, 268-277. [CrossRef] [PubMed]

40. Mohseni, R.; Hamidieh, A.A.; Verdi, J.; Shoae-Hassani, A. Safe Transplantation Of Pluripotent Stem Cell By Preventing Teratoma Formation. J. Stem Cell Res. 2014, 4, 1000212. [CrossRef]

41. Hentze, H.; Soong, P.L.; Wang, S.T.; Phillips, B.W.; Putti, T.C.; Dunn, N.R. Teratoma formation by human embryonic stem cells: Evaluation of essential parameters for future safety studies. Stem Cell Res. 2009, 2, 198-210. [CrossRef] [PubMed]

42. Fujikawa, T.; Oh, S.-H.; Pi, L.; Hatch, H.M.; Shupe, T.; Petersen, B.E. Teratoma formation leads to failure of treatment for type I diabetes using embryonic stem cell-derived insulin-producing cells. Am J. Pathol. 2005, 166, 1781-1791. [CrossRef]

43. Alper, J. Geron gets green light for human trial of ES cell-derived product. Nat. Biotechnol. 2009, 27, $213-214$. [CrossRef] [PubMed]

44. Amariglio, N.; Hirshberg, A.; Scheithauer, B.W.; Cohen, Y.; Loewenthal, R.; Trakhtenbrot, L.; Paz, N.; Koren-Michowitz, M.; Waldman, D.; Leider-Trejo, L.; et al. Donor-Derived brain tumor following neural stem cell transplantation in an ataxia telangiectasia patient. PLoS Med. 2009, 6, e1000029. [CrossRef] [PubMed]

45. Kershaw, D.B.; Beck, S.G.; Wharram, B.L.; Wiggins, J.E.; Goyal, M.; Thomas, P.E.; Wiggins, R.C. Molecular cloning and characterization of human podocalyxin-like protein. Orthologous relationship to rabbit PCLP1 and rat podocalyxin. J. Biol. Chem. 1997, 272, 15708-15714. [CrossRef] [PubMed]

46. Brandenberger, R.; Wei, H.; Zhang, S.; Lei, S.; Murage, J.; Fisk, G.J.; Li, Y.; Xu, C.; Fang, R.; Guegler, K.; et al. Transcriptome characterization elucidates signaling networks that control human ES cell growth and differentiation. Nat. Biotechnol. 2004, 22, 707-716. [CrossRef] [PubMed]

47. Schopperle, W.M.; DeWolf, W.C. The TRA-1-60 and TRA-1-81 human pluripotent stem cell markers are expressed on podocalyxin in embryonal carcinoma. Stem Cells 2006, 25, 723-730. [CrossRef] [PubMed]

48. Matsumoto, S.; Nakao, H.; Kawabe, K.; Nonaka, M.; Toyoda, H.; Takishima, Y.; Kawabata, K.; Yamaguchi, T.; Furue, M.K.; Taki, T.; et al. A cytotoxic antibody recognizing lacto- N -fucopentaose I ( LNFP I) on human induced pluripotent stem ( hiPS ) Cells *. J. Biol. Chem. 2015, 290, 20071-20085. [CrossRef] [PubMed]

49. Tang, C.; Lee, A.S.; Volkmer, J.-P.; Sahoo, D.; Nag, D.; Mosley, A.R.; Inlay, M.A.; Ardehali, R.; Chavez, S.L.; Pera, R.R.; et al. An antibody against SSEA-5 glycan on human pluripotent stem cells enables removal of teratoma-forming cells. Nat. Biotechnol. 2011, 29, 829-834. [CrossRef] [PubMed]

50. Tan, H.L.; Tan, B.Z.; Goh, W.X.T.; Cua, S.; Choo, A. In vivo surveillance and elimination of teratoma-forming human embryonic stem cells with monoclonal antibody 2448 targeting annexin A2. Biotechnol. Bioeng. 2019, 116, 2996-3005. [CrossRef] [PubMed]

51. Murayama, Y.; Oritani, K.; Tsutsui, S. Novel CD9-targeted therapies in gastric cancer. World J. Gastroenterol. 2015, 21, 3206-3213. [CrossRef]

52. Liang, P.; Miao, M.; Liu, Z.; Wang, H.; Jiang, W.; Ma, S.; Li, C.; Hu, R. CD9 expression indicates a poor outcome in acute lymphoblastic leukemia. Cancer Biomark. 2018, 21, 781-786. [CrossRef] [PubMed]

53. Wachowiak, R.; Krause, M.; Mayer, S.; Peukert, N.; Suttkus, A.; Müller, W.C.; Lacher, M.; Meixensberger, J.; Nestler, U. Increased L1CAM (CD171) levels are associated with glioblastoma and metastatic brain tumors. Medicine 2018, 97, e12396. [CrossRef] [PubMed] 
54. Guo, J.-C.; Xie, Y.-M.; Ran, L.-Q.; Cao, H.-H.; Sun, C.; Wu, J.-Y.; Wu, Z.-Y.; Liao, L.-D.; Zhao, W.-J.; Fang, W.-K.; et al. L1CAM drives oncogenicity in esophageal squamous cell carcinoma by stimulation of ezrin transcription. J. Mol. Med. 2017, 95, 1355-1368. [CrossRef] [PubMed]

55. Han, C.-P.; Yu, Y.-H.; Wang, A.-G.; Tian, Y.; Zhang, H.-T.; Zheng, Z.-M.; Liu, Y.-S. Desmoglein-2 overexpression predicts poor prognosis in hepatocellular carcinoma patients. Eur. Rev. Med. Pharm. Sci. 2018, 22, 5481-5489.

56. Brennan, D.; Mahoney, M.G. Increased expression of Dsg2 in malignant skin carcinomas: A tissue-microarray based study. Cell Adh. Migr. 2009, 3, 148-154. [CrossRef] [PubMed]

57. Khan, Z.; Shervington, A.; Munje, C.; Shervington, L. The complexity of identifying cancer stem cell biomarkers. Cancer Invest. 2013, 31, 404-411. [CrossRef] [PubMed]

58. Brewer, B.G.; Mitchell, R.A.; Harandi, A.; Eaton, J.W. Embryonic vaccines against cancer: An early history. Exp. Mol. Pathol. 2009, 86, 192-197. [CrossRef] [PubMed]

59. Li, Y.; Zeng, H.; Xu, R.H.; Liu, B.; Li, Z. Vaccination with human pluripotent stem cells generates a broad spectrum of immunological and clinical responses against colon cancer. Stem Cells 2009, 27, 3103-3111. [CrossRef]

60. Dong, W.; Qiu, C.; Shen, H.; Liu, Q.; Du, J. Antitumor effect of embryonic stem cells in a non-small cell lung cancer model: Antitumor factors and immune responses. Int. J. Med. Sci. 2013, 10, 1314-1320. [CrossRef] [PubMed]

61. Wright, A.J.; Andrews, P.W. Surface marker antigens in the characterization of human embryonic stem cells. Stem Cell Res. 2009, 3, 3-11. [CrossRef]

62. Magdelénat, H. Tumour markers in oncology: Past, present and future. J. Immunol. Methods 1992, 150, $133-143$. [CrossRef]

63. Carter, P.; Smith, L.; Ryan, M. Identification and validation of cell surface antigens for antibody targeting in oncology. Endocr. Relat. Cancer 2004, 11, 659-687. [CrossRef] [PubMed]

64. Diamandis, E.P.; Bast, R.C.; Gold, P.; Chu, T.M.; Magnani, J.L. Reflection on the discovery of carcinoembryonic antigen, prostate-specific antigen, and cancer antigens CA125 and CA19-9. Clin. Chem. 2013, 59, $22-31$. [CrossRef] [PubMed]

65. Graves, M.L.; Cipollone, J.A.; Austin, P.; Bell, E.M.; Nielsen, J.S.; Gilks, C.B.; McNagny, K.M.; Roskelley, C.D. The cell surface mucin podocalyxin regulates collective breast tumor budding. Breast Cancer Res. 2016, 18, 1-17. [CrossRef] [PubMed]

66. Amo, L.; Tamayo-Orbegozo, E.; Maruri, N.; Buqué, A.; Solaun, M.; Riñón, M.; Arrieta, A.; Larrucea, S. Podocalyxin-like protein 1 functions as an immunomodulatory molecule in breast cancer cells. Cancer Lett. 2015, 368, 26-35. [CrossRef]

67. Snyder, K.A.; Hughes, M.R.; Hedberg, B.; Brandon, J.; Hernaez, D.C.; Bergqvist, P.; Cruz, F.; Po, K.; Graves, M.L.; Turvey, M.E.; et al. Podocalyxin enhances breast tumor growth and metastasis and is a target for monoclonal antibody therapy. Breast Cancer Res. 2015, 17, 1-14. [CrossRef]

68. Borg, D.; Hedner, C.; Nodin, B.; Larsson, A.; Johnsson, A.; Eberhard, J.; Jirström, K. Expression of podocalyxin-like protein is an independent prognostic biomarker in resected esophageal and gastric adenocarcinoma. BMC Clin. Pathol. 2016, 16, 13. [CrossRef] [PubMed]

69. Laitinen, A.; Bockelman, C.; Hagstrom, J.; Kokkola, A.; Fermér, C.; Nilsson, O.; Haglund, C. Podocalyxin as a prognostic marker in gastric cancer. PLoS ONE 2015, 10, 1-12. [CrossRef] [PubMed]

70. Kaprio, T.; Fermér, C.; Hagström, J.; Mustonen, H.; Böckelman, C.; Nilsson, O.; Haglund, C. Podocalyxin is a marker of poor prognosis in colorectal cancer. BMC Cancer 2014, 14, 1-7. [CrossRef]

71. Kusumoto, H.; Shintani, Y.; Kanzaki, R.; Kawamura, T.; Funaki, S.; Minami, M.; Nagatomo, I.; Morii, E.; Okumura, M. Podocalyxin influences malignant potential by controlling epithelial-mesenchymal transition in lung adenocarcinoma. Cancer Sci. 2017, 108, 528-535. [CrossRef]

72. Jirström, K.; Ahlgren, G.; Andersson, G.; Nodin, B.; Wennersten, C.; Boman, K. Podocalyxin-like and RNA-binding motif protein 3 are prognostic biomarkers in urothelial bladder cancer: A validatory study. Biomark Res. 2017, 5, 1-10.

73. Taniuchi, K.; Furihata, M.; Naganuma, S.; Dabanaka, K.; Hanazaki, K.; Saibara, T. Podocalyxin-Like protein, linked to poor prognosis of pancreatic cancers, promotes cell invasion by binding to gelsolin. Cancer Sci. 2016, 107, 1430-1442. [CrossRef] [PubMed]

74. Modjtahedi, H.; Ali, S.; Essapen, S. Therapeutic application of monoclonal antibodies in cancer: Advances and challenges. Br. Med. Bull. 2012, 104, 41-59. [CrossRef] 
75. Scott, A.M.; Allison, J.P.; Wolchok, J.D. Monoclonal antibodies in cancer therapy. Cancer Immun. 2012, $12,14$. [PubMed]

76. Scott, A.M.; Wolchok, J.D.; Old, L.J. Antibody therapy of cancer. Nat. Rev Cancer 2012, 12, 278-287. [CrossRef]

77. Pillay, V.; Gan, H.K.; Scott, A.M. Antibodies in oncology. N. Biotechnol. 2011, 28, 518-529. [CrossRef]

78. Weiner, G.J. Building better monoclonal antibody-based therapeutics. Nat. Rev. Cancer 2015, 15, 361-370. [CrossRef]

79. Wold, E.D.; Smider, V.V.; Felding, B.H. Antibody therapeutics in oncology. Immunother. Open Access 2016, 2,1-18. [CrossRef]

80. Zhang, C.; Xu, Y.; Gu, J.; Schlossman, S.F. A cell surface receptor defined by a mAb mediates a unique type of cell death similar to oncosis. Proc. Natl. Acad. Sci. USA 2002, 95, 6290-6295. [CrossRef]

81. Loo, D.; Pryer, N.; Young, P.; Liang, T.; Coberly, S.; King, K.L.; Kang, K.; Roberts, P.; Tsao, M.; Xu, X.; et al. The glycotope-specific RAV12 monoclonal antibody induces oncosis in vitro and has antitumor activity against gastrointestinal adenocarcinoma tumor xenografts in vivo. Mol. Cancer 2007, 6, 856-865. [CrossRef] [PubMed]

82. Ohashi, R.; Kawahara, K.; Fujii, T.; Takei, H.; Naito, Z. Higher expression of EpCAM is associated with poor clinical and pathological responses in breast cancer patients undergoing neoadjuvant chemotherapy. Pathol. Int. 2016, 66, 210-217. [CrossRef]

83. Sadeghi, S.; Hojati, Z.; Tabatabaeian, H. Cooverexpression of EpCAM and c-myc genes in malignant breast tumours. J. Genet. 2017, 96, 109-118. [CrossRef] [PubMed]

84. Zhang, D.; Liu, X.; Gao, J.; Sun, Y.; Liu, T.; Yan, Q.; Yang, X. The role of epithelial cell adhesion molecule N-glycosylation on apoptosis in breast cancer cells. Tumor Biol. 2017, 39, 101042831769597. [CrossRef]

85. Battista, M.J.; Cotarelo, C.; Jakobi, S.; Steetskamp, J.; Makris, G.; Sicking, I.; Weyer, V.; Schmidt, M. Overexpression of epithelial cell adhesion molecule protein is associated with favorable prognosis in an unselected cohort of ovarian cancer patients. J. Cancer Res. Clin. Oncol. 2014, 140, 1097-1102. [CrossRef]

86. Woopen, H.; Pietzner, K.; Richter, R.; Fotopoulou, C.; Joens, T.; Braicu, E.I.; Mellstedt, H.; Mahner, S.; Lindhofer, H.; Darb-Esfahani, S.; et al. Overexpression of the epithelial cell adhesion molecule is associated with a more favorable prognosis and response to platinum-based chemotherapy in ovarian cancer. J. Gynecol. Oncol. 2014, 25, 221-228. [CrossRef] [PubMed]

87. Wang, A.; Ramjeesingh, R.; Chen, C.H.; Hurlbut, D.; Hammad, N.; Mulligan, L.M.; Nicol, C.; Feilotter, H.E.; Davey, S. Reduction in membranous immunohistochemical staining for the intracellular domain of epithelial cell adhesion molecule correlates with poor patient outcome in primary colorectal adenocarcinoma. Curr. Oncol. 2016, 23, e171-e178. [CrossRef]

88. Dai, M.; Yuan, F.; Fu, C.; Shen, G.; Hu, S.; Shen, G. Relationship between epithelial cell adhesion molecule (EpCAM) overexpression and gastric cancer patients: A systematic review and meta-analysis. PLoS ONE 2017, 12, 1-15. [CrossRef]

89. Wang, L.; Schulz, T.C.; Sherrer, E.S.; Dauphin, D.S.; Shin, S.; Nelson, A.M.; Ware, C.B.; Zhan, M.; Song, C.-Z.; Chen, X.; et al. Self-renewal of human embryonic stem cells requires insulin-like growth factor-1 receptor and ERBB2 receptor signaling. Blood 2007, 110, 4111-4119. [CrossRef]

90. Iqbal, N.; Iqbal, N. Human epidermal growth factor receptor 2 (HER2) in cancers: Overexpression and therapeutic implications. Mol. Biol. Int. 2014, 2014, 852748. [CrossRef] [PubMed]

91. Morrissey, K.; Yuraszeck, T.; Li, C.C.; Zhang, Y.; Kasichayanula, S. Immunotherapy and Novel Combinations in Oncology: Current Landscape, Challenges, and Opportunities. Clin. Transl Sci. 2016, 9, 89-104. [CrossRef]

92. Slamon, D.J.; Leyland-Jones, B.; Shak, S.; Fuchs, H.; Paton, V.; Bajamonde, A.; Fleming, T.; Eiermann, W.; Wolter, J.; Pegram, M.; et al. Use of chemotherapy plus a monoclonal antibody against HER2 for metastatic breast cancer that overexpresses HER2. N. Engl. J. Med. 2001, 344, 783-792. [CrossRef]

93. Lewis Phillips, G.D.; Li, G.; Dugger, D.L.; Crocker, L.M.; Parsons, K.L.; Mai, E.; Blättler, W.A.; Lambert, J.M.; Chari, R.V.J.; Lutz, R.J.; et al. Targeting HER2-positive breast cancer with trastuzumab-DM1, an antibody-cytotoxic drug conjugate. Cancer Res. 2008, 68, 9280-9290. [CrossRef] [PubMed]

94. Law, T.; Rowden, G.; Sullivan, A.K.; Pitzele, R. Fetal antigens in nonneoplastic conditions. Cancer Res. 1976, $36,3446-3452$.

95. Tsuchiya, N. Biomarkers for the early diagnosis of hepatocellular carcinoma. World J. Gastroenterol. 2015, 21, 10573. [CrossRef] [PubMed] 
96. Kirwan, A.; Utratna, M.; O’Dwyer, M.E.; Joshi, L.; Kilcoyne, M. Glycosylation-Based serum biomarkers for cancer diagnostics and prognostics. BioMed. Res. Int. 2015, 2015, 490531. [CrossRef]

97. Chang, Y.-T.; Huang, M.-Y.; Yeh, Y.-S.; Huang, C.-W.; Tsai, H.-L.; Cheng, T.-L.; Wang, J.-Y. A prospective study of comparing multi-gene biomarker chip and serum carcinoembryonic antigen in the postoperative surveillance for patients with stage I-III colorectal cancer. PLoS ONE 2016, 11, e0163264. [CrossRef] [PubMed]

98. Shang, X.; Zi, H.; Li, Y.; Gao, Y.; Ge, C.; Sun, Z.; Zhang, Y. Combined use of salivary biomarkers and carcinoembryonic antigen for lung cancer detection in a Chinese population. Medicine 2019, 98, e16511. [CrossRef]

99. Prager, G.W.; Braemswig, K.H.; Martel, A.; Unseld, M.; Heinze, G.; Brodowicz, T.; Scheithauer, W.; Kornek, G.; Zielinski, C.C. Baseline carcinoembryonic antigen (CEA) serum levels predict bevacizumab-based treatment response in metastatic colorectal cancer. Cancer Sci. 2014, 105, 996-1001. [CrossRef]

100. Raju, R.; Chau, D.; Cho, D.S.; Park, Y.; Verfaillie, C.M.; Hu, W.-S. Cell expansion during directed differentiation of stem cells toward the hepatic lineage. Stem Cells Dev. 2017, 26, 274-284. [CrossRef]

101. Ang, L.T.; Tan, A.K.Y.; Autio, M.I.; Goh, S.H.; Choo, S.H.; Lee, K.L.; Tan, J.; Pan, B.; Lee, J.J.H.; Lum, J.J.; et al. A roadmap for human liver differentiation from pluripotent stem cells. Cell Rep. 2018, 22, 2190-2205. [CrossRef] [PubMed]

102. Kitadani, J.; Ojima, T.; Iwamoto, H.; Tabata, H.; Nakamori, M.; Nakamura, M.; Hayata, K.; Katsuda, M.; Miyajima, M.; Yamaue, H. Cancer vaccine therapy using carcinoembryonic antigen-Expressing dendritic cells generated from induced pluripotent stem cells. Sci. Rep. 2018, 8, 1-11. [CrossRef]

103. Barkeer, S.; Chugh, S.; Batra, S.K.; Ponnusamy, M.P. Glycosylation of cancer stem cells: Function in stemness, tumorigenesis, and metastasis. Neoplasia 2018, 20, 813-825. [CrossRef]

104. Kim, Y.J.; Varki, A. Perspectives on the significance of altered glycosylation of glycoproteins in cancer. Glycoconj. J. 1997, 14, 569-576. [CrossRef] [PubMed]

105. Sougawa, N.; Miyagawa, S.; Fukushima, S.; Kawamura, A.; Yokoyama, J.; Ito, E.; Harada, A.; Okimoto, K.; Mochizuki-Oda, N.; Saito, A.; et al. Immunologic targeting of CD30 eliminates tumourigenic human pluripotent stem cells, allowing safer clinical application of hiPSC-based cell therapy. Sci. Rep. 2018, 8, 1-12. [CrossRef] [PubMed]

(C) 2019 by the authors. Licensee MDPI, Basel, Switzerland. This article is an open access article distributed under the terms and conditions of the Creative Commons Attribution (CC BY) license (http://creativecommons.org/licenses/by/4.0/). 